Jelena Andrašić'
Vera Mirović $^{2}$
Nada Milenković $^{3}$
Miloš Pjanić $^{4}$
Branimir Kalaš $^{5}$
JEL: C38, F36, F37, G34

DOI: $10.5937 /$ industrija46-14975

UDC: 005.591.41:334.7

339.13.017:664(497.11)

Original Scientific Paper

\title{
The Characteristics of Takeover Targets: Evidence from Food Industry in Serbia
}

\author{
Article history: \\ Received: 11 September 2017 \\ Sent for revision: 2 October 2017 \\ Received in revised form: 25 July 2018 \\ Accepted: 25 July 2018 \\ Available online: 2 October 2018
}

\begin{abstract}
This study analyses the characteristics of target companies from food industry that were taken over by foreign investors in the Serbian market. The aim of the study is to determine: Can future target companies be predicted based on the characteristics of target companies that have already been taken over in the Serbian market? The study compares the indicators of profitability, liquidity, leverage and efficiency of 30 target companies from the food industry with the industry' average. The study includes multivariate analysis of variance (Manova) and Discriminant analysis in order to identify the difference between observed indicators. The liquidity and leverage indicator showed a statistically significant difference compared to average values. Group classification is $95 \%$ and sample homogeneity is $90 \%$ which leads to a conclusion that target companies can be predicted with extremely high reliability.
\end{abstract}

Keywords: Takeover, Food industry, Profitability, Liquidity, Leverage, Efficiency.

\section{Karakteristike ciljnih preduzeća u preuzimanju:Primer prehrambene industrije u Srbiji}

Apstrakt. U ovom radu, analizirane su karakteristike ciljnih preduzeća koja su preuzeta od strane stranih investitora na tržištu Srbije. Cilj ove studije jeste da

\footnotetext{
${ }^{1}$ University of Novi Sad, Faculty of Economics, Subotica, Serbia, jelenadj@ef.uns.ac.rs

${ }^{2}$ University of Novi Sad, Faculty of Economics, Subotica, Serbia

${ }^{3}$ University of Novi Sad, Faculty of Economics, Subotica, Serbia

${ }^{4}$ University of Novi Sad, Faculty of Economics, Subotica, Serbia

${ }^{5}$ University of Novi Sad, Faculty of Economics, Subotica, Serbia
} 
Andrašić J., et al: The Characteristics of Takeover Targets: Evidence from Food...

utvrdi: Da li se budući targeti mogu predvideti na osnovu karakteristika preduzeća koja su već preuzeta na tržištu Srbije? Studija poredi pokazatelje profitabilnosti, likvidnosti, zaduženosti i efikasnosti 30 ciljnih preduzeća iz prehrambene industrije sa prosekom privredne grane. Studija uključuje multivarjantnu analizu varijanse (MANOVA) i diskriminativnu analizu kako bi se identifikovala razlika između posmatranih pokazatelja. Kod pokazatelja likvidnosti i leveridža utvrđena je statistički značajna razlika u odnosu na prosečne vrednosti. Klasifikacija grupa je na nivou od 95\% i homogenost uzorka $90 \%$ što upućuje na zaključak da se ciljna preduzeća mogu predvideti sa izuzetno visokom pouzdanošću.

Ključne reči: preuzimanja, prehrambena industrija, profitabilnost, likvidnost, leveridž, efikasnost.

\section{Introduction}

In the initial phase of transition, takeover processes were done in a form of acquisition of assets - privatization of the existing state-owned companies. The largest number of foreign investments came to Serbia through the privatization of state-owned companies operating in telecommunications, banking and food industry. According to D'Souza et al (2017), privatization processes involve a whole series of reforms in the economic, political, legal and financial system, and the privatization of state-owned enterprises has a significant role in transition countries. Foreign direct investments grew from 2001, reaching their maximum in 2006 when they amounted to $14.3 \%$ of the GDP (gross domestic product). Onset of the world economic crisis in the summer of 2008 led to a rapid decline in investment activity worldwide and in Serbia as well. The gross domestic product grew at an average annual rate of $3.5 \%$ from 2001 to 2011 , despite the fact that the first moderate decline of $3.5 \%$ was observed in 2009 due to negative effects of the global crisis. In the period from 2001-2011, growth rate of production industry was $0.7 \%$, where processing industry dictates growth pace to a significant extent $0.4 \%$ (food production amounts to $1.6 \%$, while beverage production amounts to $0.5 \%$ ). Food industry accounts for $18.6 \%$ of the total Industry, which is the highest percentage share according to the Chamber of commerce and industry of Serbia (2017). Contribution of the food industry to GDP is 3.3\%. Analysing the period of transition in Serbia, the authors Nikolić and Zubović (2013) conclude that there have been significant structural changes in the manufacturing industry, but that did not result in a sufficient improvement in comparison with other transition countries and the average EU countries.

Since 2001 the new beginning of transition in Serbia has been aimed at reaching the macroeconomic stability. There was an increase in growth rate of 
Andrašić J. et al: The Characteristics of Takeover Targets: Evidence from Food...

the gross domestic product, the decline in inflation and market liberalization which gave a positive signal to investors to come to the Serbian market. Since Serbia in the second round of transitional reforms did not even achieve $60 \%$ of the GDP it had had in 1989 when the transition first had begun, the Serbian market was appealing to foreign investors due to its great growth potential. Provided that there is no economic growth of the country without foreign investments, many authors in their research dealt with studying determinants which influence the choice of foreign investors to invest their capital in a certain country (Savoiu et al., 2013; Brouthers \& Brouthers, 2000; Mudambi \& Mudambi, 2002; Bevan \& Estrin 2004; Mahmoodi \& Mahmoodi, 2016; Andrašić et al., 2017).

In addition to researching institutional variables for attracting foreign investors, a large number of empirical studies examined the characteristics of target companies (Aharony \& Barniv, 2004; Harford et al., 2012; Humphery-Jenner \& Powell, 2014; Mesulis et al., 2007; Moeller et al., 2004; Akhigbe et al., 2007; Offenberg, 2009; Gorton et al., 2005; Peng, 2006).

According to Alhenawi and Stilwell (2017, p.1042) "Intuitively, an M\&A transaction creates value when the target's potential value as a division of a competent acquirer is greater than the target's pre-acquisition value as a stand-alone entity." Through a discriminatory analysis, the authors have tested the hypothesis, that acquisitor's competencies are important for the success of acquisition in addition to the pre-acquisition value of the goals. Campa and Kedia (2002) also support the view that firm-specific characteristics should be considered when evaluating corporate acquisition events.

In recent years, there is increasing evidence that in the takeover process some other factors get importance over the commonly used data from financial statements by analysing and selecting the target companies. In their researches, authors Alimov and Officer (2017), Ahern et al (2015), Fresard et al (2017), Contractor et al (2014) have shown that these factors include cultural distance between acquirers and target companies, the difference in the protection of the intellectual property rights and sectoral affiliation between the target company and the acquirer.

Also, a numerous studies researched predictive models for determining future targets based on the characteristics of companies which were already taken over (Graham et al., 2001; Baker \& Kennedy, 2002; Branch \& Yang, 2003; Officer, 2003; Schwert, 2000).

The aim of the study is to determine:

1. Who were targets, i.e. target companies in the Serbian market?

2. Do the characteristics of target companies in the Serbian market coincide with the characteristics of those in other empirical studies? 
Andrašić J., et al: The Characteristics of Takeover Targets: Evidence from Food...

3. Can future targets, i.e. target companies in the food industry be predicted based on the characteristics of target companies that have already been taken over in the Serbian market?

However, in transition countries, such as Serbia, there are problems with the availability of any data. In this paper, the authors analyse target companies in the food industry using data from financial statements. In Serbia, there is no database or agency that provides data on mergers and acquisitions, so it is very difficult to get information on the impact of the takeover process on the target company. Bearing that in mind, this authors' research significantly contributes to the economic policymakers, giving them information about the characteristics of the companies in the food industry which might become targets in the takeover process.

\section{Literature Review}

A large number of empirical studies researched the characteristics of target companies. The most commonly used criterion for the comparison was the average of industry in which target companies operated. Most studies analysed the following determinants of target companies: sale, $\mathrm{HHI}$ (Herfindahl-Hirschman Index), participation of the board of directors in the equity capital, ROA, ROE, research and development to assets ratio, operating cash flow to sales ratio - liquidity ratio, Tobin $Q$ ratio, debt to assets ratio - leverage, growth rate, share of fixed assets in total assets, etc.

There are many studies which researched determinants such as profitability, liquidity, leverage and efficiency (Meeks, 1977; Jensen, 1986; Palepu, 1986; Wruck 1990; Ambrose \& Megginson, 1992; Song \& Walkling, 1993; Clark \& Ofek, 1994; Singh,1997; Graham et al., 2001; North, 2001; Baker \& Kennedy, 2002; Eichholtz \& Kok, 2008; Harrison et al., 2014).

One of the first research studies done on the market for corporate control in Great Britain in the 1960s concluded that target companies were less profitable and had a lower growth rate compared to the industry average (Singh, 1997). According to Baker and Kennedy (2002), target companies are more often less profitable measured by indicators ROA and ROE compared to the industry average. This corresponds to the research of Palepu (1986) according to which companies with lower return rate are targets of hostile attacks. There is a high level of agreement in the literature on measuring the profitability of target companies. Most studies confirm that target companies show a decline in profitability and performance indicators compared to the industry average. First empirical studies to confirm this were the aforementioned studies of the authors Singh (1997) and Meeks (1977). These authors also studied takeover likelihood and came to a conclusion that 
Andrašić J. et al: The Characteristics of Takeover Targets: Evidence from Food...

companies whose profitability was below the industry average were more often takeover targets.

Company's liquidity level and leverage are considered as key characteristics in choosing target companies. Target companies are more often a takeover target, if they have liquidity level above the industry average and degree of leverage below the industry average, as reported by Palepu (1986). Ambrose and Megginson (1992) also concluded that low leverage and a big share of fixed assets in total assets increased takeover likelihood. According to Jensen (1986), low leverage is an especially appealing characteristic, because it leaves the acquirer with the possibility to use available borrowing capacity after the takeover of the target company. Harrison et al (2014) conclude that a low leverage increases the likelihood of a firm becoming an acquisition target, which is confirmed by previous studies (Wruck, 1990; Clark \& Ofek, 1994).

Eichholtz and Kok (2008) analyse 122 mergers and acquisitions over the 1999 - 2004 period. They compare targets, acquirers and a control sample using a pre-acquisition performance study, a two-sample t-test and consequently a multinomial logistic approach. Their study confirmed that targets have lower operational performance compared to companies that represented the control group. Song and Walking (1993), North (2001) and Graham et al (2001) also point out that the lower performance of the company increases the likelihood of these companies to be targeted for acquisition.

The acquisition processes of companies are characterized by cyclical activity. The first wave of the takeover process acquires on the US market was in the late 19th and early 20th centuries. A significant takeover activity in Serbia started at the beginning of the 21st century. Considering that fact, it is to notice that there is a time gap between the analysis of the target companies in the US from the literature review and the analysis of the target companies in Serbia in this research. This research gives its contribution defining the attractiveness determinants of the Serbian market for the future investors. It is especially valuable for the investors in the food industry because this market has not been explored yet, by analysing the companies as potential targets.

In accordance with the above listed empirical studies that dealt with the characteristics of target companies, we come to a conclusion that there is a great deal of agreement in the literature that target companies have the following characteristics: lower profitability, lower leverage, higher liquidity and higher efficiency compared to the industry average.

In this part of the study, the following hypotheses will be tested on the example of the Serbian market:

H1: Potential takeover candidates are companies with lower leverage compared to the industry average. 
Andrašić J., et al: The Characteristics of Takeover Targets: Evidence from Food...

H2: Potential takeover candidates are companies with higher liquidity compared to the industry average.

H3: Potential takeover candidates are companies with lower profitability compared to the industry average.

H4: Potential takeover candidates are companies with higher efficiency compared to the industry average.

\section{Materials and Method}

The sample includes 30 companies from the food industry in chosen sectors. Considering that there is a total of 263 companies in the chosen sectors founded by legal entities, 167 thereof are in liquidation, and of remaining 96 companies, 30 companies selected for the analysis represent $33 \%$ of the total number which is considered to be a very representative sample for drawing valid conclusions. The sample consists of companies in the following sectors: 1032 - Juice production from fruit and vegetables; 1051 - Milk and cheese production; 1072 - Production of toast, crackers, biscuits and cakes; 1082Production of coco, chocolate and confectionary products; 1089- Production of other food products; 1105 - Beer production; 1107 - Production of refreshing drinks and mineral water.

The study compares profitability, liquidity, leverage and efficiency determinants of the target companies with the industry average a year before the takeover. The Business Registers Agency (financial reports of companies and macroeconomic communications relative to the whole economy of the country) is used as a database in this study for chosen companies' determinants and for determinants of the industry average.

Table 1 Chosen company determinants

\begin{tabular}{|c|l|}
\hline Profitability & $\begin{array}{l}\text { ROA }=\frac{\text { Net income }}{\text { Total Assets }} \times 100 \\
\mathrm{ROE}=\frac{\text { Net income }}{\text { Total equity }} \times 100\end{array}$ \\
\hline Leverage (LV) & $\begin{array}{l}\text { Leverage }=\frac{\text { Borrowed assets }}{\text { Total assets }} \\
\text { Debt-to-capital ratio }=\frac{\text { Long-term debt }}{\text { Capital }}\end{array}$ \\
\hline Liquidity (LQ) & Liquidity ratio $=\frac{\text { Liquid assets }}{\text { Short -term liabilities }}$ \\
\hline Efficiency (EF) & Share of fixed assets in total assets $=\frac{\text { Fixed assets }}{\text { Fixed assets +current asse ts }}$ \\
\hline
\end{tabular}

Source: Authors' table based on Gogan, P. A. (2004, p.671). Mergers, acquisitions, and Corporate Restructurings. New York. John Wiley\&Sons, Inc. 
Andrašić J. et al: The Characteristics of Takeover Targets: Evidence from Food...

Most often used ratios for testing company's profitability are ROA (return on assets ratio) and ROE (return on equity ratio). According to Jakšić et al (2015), ROA ratio should be higher than 0.1 and ROE ratio should be higher than 0.15 . Liquidity is the ability of a company to pay off its immediate liabilities. Ratio of current liquidity should be greater than one. Leverage gauges the share of borrowed funds in total company assets, i.e. share of long-term debt in total capital. This ratio should be as low as possible and in accordance with the efficiency ratio, which shows the amount of fixed assets in total company assets, i.e. it shows the amount of fixed assets financed with owners' equity (Gogan, 2004).

Provided that the variables are parametric, the analysis will be done using parametric methods. Methods used in the study are multivariate statistical methods MANOVA, discriminant analysis of univariate methods ANOVA and t-test. Discriminant coefficient serves to distinguish which variables determine the subsample specificity and which variables are to be excluded from further analysis. Purpose of using mathematical-statistical analysis is to determine the characteristics of both subsamples - chosen variables and the industry average, homogeneity and distance between them, in order to perform precise prediction and forecast with certain reliability. The study tests whether there is a difference between chosen variables of the food industry and the industry average, in order to prove the stated hypotheses.

\section{Results and Discussion}

Based on descriptive statistics, results show: mean value, standard deviation (Sd), minimums and maximums of all values, the coefficient of variation (C.var.), confidence interval, a measure of asymmetry - Skewness, a measure of flatness - Kurtosis and Kolmogorov-Smirnov test values.

Table 2 Measures of central tendency and dispersion parameters and measures of asymmetry and flatness of company's business performance a year before the takeover for chosen company determinants

\begin{tabular}{|l|l|l|l|l|l|l|l|l|l|l|}
\hline & $\begin{array}{l}\text { Mean } \\
\text { value }\end{array}$ & Sd & min & max & C.var. & \multicolumn{2}{l}{$\begin{array}{l}\text { Confidence } \\
\text { interval }\end{array}$} & Sk & Ku & $\begin{array}{l}\text { Distribution } \\
\text { of Values }\end{array}$ \\
\hline ROE & -23.45 & 84.19 & -294.5 & 44.5 & 359.07 & -54.89 & 8.00 & -2.41 & 4.75 & .014 \\
\hline ROA & -1.96 & 21.86 & -98.8 & 24.9 & 1116.02 & -10.12 & 6.21 & -2.93 & 11.06 & .396 \\
\hline LV & .41 & .24 & .1 & .9 & 58.85 & .32 & .50 & .42 & -.56 & .496 \\
\hline $\mathrm{D} / \mathrm{C}$ & .52 & 1.41 & .0 & 7.6 & 270.57 & -.01 & 1.05 & 4.40 & 19.17 & .001 \\
\hline LQ & 1.81 & 1.42 & .1 & 6.7 & 78.56 & 1.28 & 2.34 & 1.81 & 3.38 & .246 \\
\hline EF & .61 & .18 & .0 & 1.0 & 30.45 & .54 & .68 & -.77 & 2.27 & .995 \\
\hline
\end{tabular}

Source. Authors

Note. asymmetry and flatness values in the interval from -.04 to .04 were not discussed 
Andrašić J., et al: The Characteristics of Takeover Targets: Evidence from Food...

Minimal (min) and maximal (max) values of the success of business performance a year before the takeover for chosen company determinants show values in the expected range. Higher values of the coefficient of variation (c.var) indicate heterogeneity of all chosen company determinants. ROE (359.07), ROA (1116.02), Leverage (58.85), Debt/Capital (270.57), Liquidity (78.56), and Efficiency (30.45). Higher values of Skewness (Sk) indicate a negatively-skewed distribution, meaning that the distribution curve is leaning more towards higher values. In other words, there are higher values compared to the normal distribution with Leverage (.42), Debt/Capital (4.40), Liquidity (1.81). Smaller values of Skewness (Sk) indicate a positively-skewed distribution, meaning that the distribution curve is leaning more towards smaller values. In other words, there are smaller values compared to the normal distribution with ROE (-2.41), ROA (-2.93), Efficiency (-.77). Higher values of Kurtosis (Ku) indicate an elongated tail with ROE (4.75), ROA (11.06), Debt/Capital (19.17), Liquidity (3.38) and Efficiency (2.27). Negative Kurtosis $(\mathrm{Ku})$ indicates a flat distribution with Leverage (-.56). Distribution of values is mostly in the range of normal distribution (p) with ROA (.40), Leverage (.50), Liquidity (.25) and Efficiency (1.00). Distribution of values deviates from the normal distribution (p) with ROE (.01) and Debt/Capital (.00).

Table 3 Measures of central tendency and dispersion parameters and measures of asymmetry and flatness of the industry average a year before the takeover

\begin{tabular}{|l|l|l|l|l|l|l|l|l|l|l|}
\hline & $\begin{array}{l}\text { Mean } \\
\text { value }\end{array}$ & Sd & min & max & C.var. & \multicolumn{2}{|l|}{$\begin{array}{l}\text { Confidence } \\
\text { Interval }\end{array}$} & Sk & Ku & $\begin{array}{l}\text { Distribution } \\
\text { of values }\end{array}$ \\
\hline ROE & -1.94 & 3.20 & -8.6 & 3.2 & 164.52 & -3.14 & -.75 & -.02 & -.26 & .141 \\
\hline ROA & -.90 & 1.30 & -3.4 & 1.3 & 145.27 & -1.38 & -.41 & .23 & -.36 & .063 \\
\hline LV & .66 & .06 & .6 & .7 & 9.03 & .64 & .68 & -.23 & -1.75 & .153 \\
\hline D/C & .60 & .15 & .4 & .8 & 25.18 & .55 & .66 & -.22 & -1.70 & .225 \\
\hline LQ & .94 & .08 & .9 & 1.0 & 8.63 & .91 & .97 & .22 & -1.56 & .107 \\
\hline EF & .58 & .06 & .5 & .6 & 9.92 & .56 & .60 & -.26 & -1.59 & .250 \\
\hline
\end{tabular}

Source. Authors

Minimal (min) and maximal (max) values of the success of the business performance of the branch of the industry a year before the takeover for chosen company determinants show values in the expected range. Higher values of the coefficient of variation (k.var) indicate heterogeneity of the mean values of chosen determinants ROE (164.52), ROA (145.27) and Debt/Capital (25.18). Values of the coefficient of variation (c.var) indicate homogeneity of characteristics Leverage (9.03), Liquidity (8.63) and Efficiency (9.92). Higher values of Skewness (Sk) indicate a negatively-skewed distribution, meaning that the distribution curve is leaning more towards higher values. In other words, there are higher values compared to the normal distribution with ROA 
Andrašić J. et al: The Characteristics of Takeover Targets: Evidence from Food...

(.23) and Liquidity (.22). Lower values of Skewness (Sk) indicate a positivelyskewed distribution, meaning that the distribution curve is leaning more towards smaller values. In other words, there are smaller values compared to the normal distribution in Leverage (-.23), Debt/Capital (-.22) and Efficiency (.26). Values of Skewness (Sk) indicate that the distribution is not asymmetric with ROE (-.02). Negative Kurtosis $(\mathrm{Ku})$ indicates a flat distribution with ROE (-.26), ROA (-.36), Leverage (-1.75), Debt/Capital (-1.70), Liquidity (-1.56) and Efficiency (-1.59). Distribution of values is mostly in the range of normal distribution (p) with ROE (.14), Leverage (.15), Debt/Capital (.22), Liquidity (.11) and Efficiency (.25). Distribution of values deviates from the normal distribution (p) with ROA (.06).

After the layout of the results of descriptive statistics, this part of the study will show the difference between chosen company determinants, i.e. the stated hypotheses will be accepted or rejected, in order to assess the results and usefulness of further consideration, determine the direction and methodological priorities for their processing. Then, if the conditions are met, the characteristics and homogeneity of each chosen company determinant will be defined, as well as the distance between them.

Table 4 Significance of the difference between chosen company determinants and average values for chosen determinants a year before the takeover

\begin{tabular}{|l|r|r|r|r|r|}
\hline Effect (a) & \multicolumn{1}{|c|}{ Value } & \multicolumn{1}{c|}{ F } & Hypothesis df & \multicolumn{1}{c|}{ Error df } & \multicolumn{1}{c|}{ Sig. } \\
\hline Pillai's Trace & .648 & $16.287^{\mathrm{D}}$ & 6.000 & 53.000 & .000 \\
Wilks' Lambda & .352 & $16.287^{\mathrm{D}}$ & 6.000 & 53.000 & .000 \\
Hotelling's Trace & 1.844 & $16.287^{\mathrm{D}}$ & 6.000 & 53.000 & .000 \\
Roy's Largest Root & 1.844 & $16.287^{\mathrm{D}}$ & 6.000 & 53.000 & .000 \\
\hline a. Design. Intercept + V1 \\
b. Exact statistic
\end{tabular}

Source. Authors

Based on the above shown table 4, it can be concluded that the result of multivariate statistical method MANOVA $(p=.000)$, is below the significance threshold $(p<0.05)$. That further implies that there is the statistically significant difference between analysed determinants of studied companies in the food industry and industry average.

Table 5 Discriminant analysis (Wilks' Lambda)

\begin{tabular}{|l|r|r|r|r|}
\hline Test of Function(s) & Wilks' Lambda & Chi-square & df & \multicolumn{2}{|c|}{ Sig. } \\
\hline 1 & .352 & 57.482 & & 6 \\
\hline
\end{tabular}

Source. Authors 
Andrašić J., et al: The Characteristics of Takeover Targets: Evidence from Food...

Based on the above shown table 5 , it can be concluded that the result of the discriminant analysis method MANOVA $(p=.000)$, is below the significance threshold $(p<0.05)$. That further implies that there is the statistically significant difference between analysed determinants of studied companies in the food industry and industry average.

Table 6 Canonical Correlation (Eigenvalues)

\begin{tabular}{|l|c|c|c|c|}
\hline Function & Eigenvalue & $\%$ of Variance & Cumulative $\%$ & CanonicalCorrelation \\
\hline 1 & $1.844^{\mathrm{a}}$ & 100.0 & 100.0 & .805 \\
\hline a. First 1 canonical discriminant functions were used in the analysis.
\end{tabular}

Source. Authors

Canonical correlation coefficient of .805 implies a very strong model and important significance and correlation of discriminant variables in the formation of differences. Both canonical coefficient and the Wilks' lambda result $(\mathrm{sig}=.000)$ confirm a good choice of company determinants in the formation of differences.

Table 7 Analysis of differences between chosen company determinants and average values for chosen determinants a year before the takeover

\begin{tabular}{|l|r|r|r|r|}
\hline & Wilks' Lambda & \multicolumn{1}{|c|}{ F } & \multicolumn{1}{c|}{$\begin{array}{c}\text { Coefficient.of } \\
\text { discrimination }\end{array}$} \\
\hline Roe & .967 & 1.954 & .167 & .827 \\
Roa & .999 & .071 & .791 & .393 \\
LV & .654 & 30.648 & .000 & 1.045 \\
D/C & .998 & .096 & .758 & .213 \\
LQ & .838 & 11.237 & .001 & .035 \\
EF & .991 & .516 & .476 & .273 \\
\hline
\end{tabular}

Source. Authors

Calculating the discrimination coefficient isolates the variables that define the specificity of subsamples (subsample: companies and subsample: industry average) and variables which are to be excluded from further processing. The coefficient of discrimination indicates that the biggest contribution to discrimination between chosen company determinants and their average values was with (i.e. the biggest difference was observed with) Leverage (1.045), ROE (.827), ROA (.393), Efficiency (.273), Debt/Capital (.213) and Liquidity (.035). Since $p<0.01$ is below the significance threshold with Leverage (.000) and Liquidity (.001), it can be concluded that these two determinants differ substantially between chosen company sample and the industry average. Since $p>0.01$ is above the significance threshold with ROE (.167), ROA (.791), Debt/Capital (.758) and Efficiency (.476), it can be concluded that there isn't a substantial difference of these determinants between company sample and the industry average. However, discriminant 
Andrašić J. et al: The Characteristics of Takeover Targets: Evidence from Food...

analysis, which is more complex than MANOVA, included these determinants into analysis as latent variables and showed a significant difference between chosen company determinants and average values. Based on the above considerations and analysis of the sample of 30 companies and in accordance with the used methodology, logical sequence of the study is determining the characteristics and homogeneity of all chosen company determinants. Since the discriminant analysis showed $(p=.000)$ that there is a significant difference, which further implies that there is a clearly defined border between chosen company determinants, i.e. it is possible to determine the characteristics of all chosen determinants a year before the takeover.

Table 8 Characteristics and homogeneity of chosen company determinants and average values a year before the takeover

\begin{tabular}{|c|c|c|c|c|}
\hline $\begin{array}{l}\text { Dependent } \\
\text { Variable }\end{array}$ & V1 & Mean & $\downarrow \uparrow$ & Contribution\% \\
\hline Roa & $\begin{array}{l}1 \\
2 \\
\end{array}$ & $\begin{array}{r}-1.959 \\
-.896 \\
\end{array}$ & $\downarrow$ & 14.106 \\
\hline Roe & $\begin{array}{l}1 \\
2 \\
\end{array}$ & $\begin{array}{r}-23.446 \\
-1.943 \\
\end{array}$ & $\downarrow$ & 29.684 \\
\hline LV & $\begin{array}{l}1 \\
2\end{array}$ & $\begin{array}{l}.408 \\
.658\end{array}$ & $\downarrow$ & 37.509 \\
\hline $\mathrm{D} / \mathrm{C}$ & $\begin{array}{l}1 \\
2\end{array}$ & $\begin{array}{l}.522 \\
.602\end{array}$ & $\downarrow$ & 7.645 \\
\hline LQ & $\begin{array}{l}1 \\
2 \\
\end{array}$ & $\begin{array}{r}1.808 \\
.937 \\
\end{array}$ & $\uparrow$ & 1.256 \\
\hline EF & $\begin{array}{l}1 \\
2\end{array}$ & $\begin{array}{l}.606 \\
.580\end{array}$ & $\uparrow$ & 9.799 \\
\hline
\end{tabular}

Source. Authors

The above presented table 8 , based on the contribution of the variable to the characteristics (\% contribution) leads to a conclusion that the biggest contribution in creating the difference between determinants of chosen companies and industry average is made by determinants in the following order Leverage (37.51\%), ROE (29.68\%), ROA (14.11\%), Efficiency $(9.80 \%)$, Debt/Capital (7.65\%) and Liquidity (1.26\%). Based on the obtained results from the above presented table, it can be concluded that the target companies from the food industry in the Republic of Serbia have the following 
Andrašić J., et al: The Characteristics of Takeover Targets: Evidence from Food...

characteristics: lower leverage (Leverage* ${ }^{*}$ Debt/Capital) than the industry average, lower profitability (ROE, ROA) than the industry average, higher efficiency than the industry average and higher liquidity* than the industry average. In order to make a prognosis with certain reliability, it is necessary to examine the sample homogeneity and whether the groups were classified in a manner to ensure model validity.

Table 9 Classification Resultsa,c

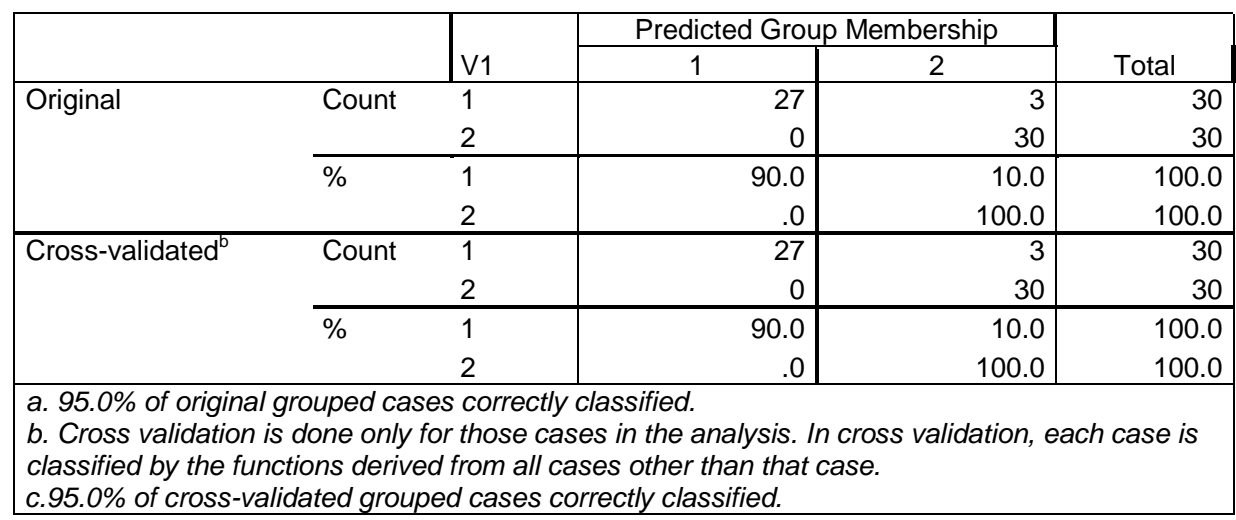

Source. Authors

The table shows that 27 of 30 companies have the characteristics of chosen determinants $(\mathrm{n} / \mathrm{m})$ and thus homogeneity of the sample is $90 \%$, leaving 3 companies with other characteristics and not those of the chosen sample. Since sample homogeneity is $90 \%$, the forecast can be made with certain reliability. In other words, it can be concluded with the certainty of $95 \%$ that companies in the food industry whose characteristics are similar to those of the chosen company determinants in the sample can become targets of hostile attack in the Serbian market. Reliability of $95 \%$ represents a very good indicator of the original classification of groups and classification of groups through the coefficient of determination.

Results confirm the hypothesis $\mathrm{H} 1$ that potential takeover candidates are companies in the food industry with lower leverage compared to the industry average, where that difference was also significant. This research is consistent with the previously undertaken studies by Palepu (1986), Ambrose and Megginson (1992), Wruck (1990), Jensen (1986), Clark and Ofek (1994). Hypothesis $\mathrm{H} 2$ that potential takeover candidates are companies in the food industry with higher liquidity compared to the industry average is also accepted which is in line with previous studies of Palepu (1986) and Harrison et al (2014). As previously shown, two determinants leverage and liquidity differ substantially, i.e. those two determinants of chosen companies differ 
Andrašić J. et al: The Characteristics of Takeover Targets: Evidence from Food...

significantly from the results of those two determinants for the whole branch of industry. This leads to a conclusion that in the process of takeover, foreign investors were particularly interested in companies with lower leverage because, as we have seen, the contribution to creating a difference for that variable was the biggest (37.51\%). Low leverage enabled foreign investors to significantly increase the leverage in first years after the takeover, in accordance with the fact that most takeovers are financed through bank loans or another form of leverage. Unutilized borrowing capacity along with high liquidity (higher than the industry average), indicates that companies which were targets of the takeovers, were capable of covering their immediate liabilities and that leverage over a certain point should not endanger their liquidity. Although profitability and efficiency determinants did not differ significantly, they were included in the analysis by the discriminant analysis approach based on the coefficient of discrimination and contribution of variables to characteristics.

Classification of groups of $95 \%$, as well as high canonical correlation coefficient, confirm the model's strength, thus proving hypotheses $\mathrm{H} 3$ and $\mathrm{H} 4$ that target companies in the food industry in the Republic of Serbia had lower profitability and higher efficiency compared to the industry average. Low profitability in comparison to the industry average indicates that companies are not run in the optimal manner and that after the takeover with the increase in leverage and realizing the effects of financial lever there can be a significant boost in profitability and therefore positive postoperative performances for the acquirer. The low profitability of the target in their research was confirmed by Singh (1997), Palepu (1986), Meeks (1977), Baker and Kennedy (2002).

\section{Conclusion}

According to the performed study, it can be concluded that the following study aims have been met.

(1) In the Republic of Serbia, takeover targets were companies in the food industry with the following characteristics: low leverage (leverage*, debt/capital), low profitability (ROA, ROE), higher liquidity* and higher efficiency compared to the industry average, where the determinants leverage and liquidity differed significantly from the average.

(2) Characteristics of target companies in the Republic of Serbia coincide with those of the target companies in other empirical studies shown in this paper.

(3) Since the homogeneity of the sample of $90 \%$ is considered very high it is possible to predict takeover targets. That is, with a certainty of $90 \%$ it can be 
Andrašić J., et al: The Characteristics of Takeover Targets: Evidence from Food...

concluded that companies operating in the Serbian market which have not yet been taken over but have low leverage, low profitability, higher liquidity and higher efficiency compared to the industry average, may become targets of hostile attacks.

Based on the given analysis of differences of chosen determinants between companies in the sample and the industry average, it can be concluded that takeover targets in the food industry did not use the effects of financial leverage in an appropriate way, or an increase in the share of borrowed funds to total equity, which reflected negatively in their profitability. Companies in the Serbian market which are not optimally run but have high efficiency and liquidity are especially attractive to takeovers, since foreign investors can significantly improve financial performances of the company by simply replacing bad management and financial politics. The market for corporate control forces managers to optimally run companies since missed financial opportunities can encourage foreign investors to make an offer for a takeover and achieve better financial performances.

\section{References}

Aharony, J., \& Barniv, R. (2004). Using financial accounting information in the governance of takeovers. An analysis by type of acquirer. Journal of Accounting and Public Policy, 23, 321-349.

Ahern, K.R., Daminelli, D., \& Fracassi, C. (2015). Lost in translation? The effect of cultural values on mergers around the world. Journal of Financial Economics, $117,165-189$.

Akhigbe, A., Martin, A. D., \& Whyte, A. M. (2007). Partial acquisitions, the acquisition probability hypothesis, and the abnormal returns to partial targets. Journal of Banking\&Finance, 31, 3080-3101.

Alhenawi, Y., \& Stilwell, M. (2017). Value creation and the probability of success in merger and acquisition transactions. Review of Quantitative Finance and Accounting, 49(4), 1041-1085.

Alimov, A., \& Officer, S.M., (2017). Intellectual property rights and cross-border mergers and acquisitions. Journal of Corporate Finance, 45, 360-377.

Ambrose, B. W., \& Megginson, W. L. (1992). The role of asset structure, ownership structure, and takeover defenses in determining acquisition likelihood. Journal of Financial and Quantitative Analysis, 27, 575-589.

Andrašić, J., Milenković, I., \& Milenković, N. (2017), Analysis of the external growth factors in the selected countries of Southeast Europe. Annals of the Faculty of Economics in Subotica, 53, 173-185.

Baker, G. P., \& Kennedy, R. E. (2002). Survivorship and the economic grim reaper. Journal of Low, Economics \& Organizations, 18, 324-361.

Berger, P., \& Ofek, E. (1996). Bustup takeovers of value-destroying diversified firms. Journal

Finance, 51, 1175-1200. 
Andrašić J. et al: The Characteristics of Takeover Targets: Evidence from Food...

Bevan, A., Estrin, S., \& Meyer, K. (2004). Foreign investment location and institutional development in transition economies. International Business Review, 13, 4364.

Branch, B., \& Yang, T. (2003). Predicting Successful Takeovers and Risk Arbitrage. Quarterly Journal of Business and Economics 42, 3-18.

Brouthers, K. D., \& Brouthers, L. E. (2000). Acquisition or greenfield start-up? Institutional, cultural and transaction cost influences. Strategic Management Journal, 21, 89-97.

Campa, J. M., \& Kedia, S. (2002). Explaining the diversification discount. The Journal of Finance, 57, 1731-1762.

Chamber of commerce and industry of Serbia http.//www.pks.rs/PrivredaSrbije.aspx?id=17\&p=2\&, taken10.04.2017.

Clark, K., \& Ofek, E. (1994). Mergers as a means of restructuring distressed firms: an empirical investigation. Journal of Financial and Quantitative Analysis, 29(4), 541-565.

Contractor, F. J., Lahiri, S., Elango, B., \& Kundu, S. K. (2014). Institutional, cultural and industry related determinants of ownership choices in emerging market FDI acquisitions. International Business Review, 23(5), 931-941.

D'Souza, J., Megginson, L.W., Ullah, B., \& Wei, Z. (2017). Growth and growth obstacles in transition economies. Privatized versus de novo private firms. Journal of Corporate Finance; 42, 422-438.

Eichholtz, P. M. A., \& Kok, N. (2008). How does the market for corporate control function for property companies. Journal of Real Estate Finance and Economics, 36(2), 141-163.

Fresard, L., Hege, U., \& Phillips, G. (2017). Extending industry specialization through cross-border acquisitions. The Review of Financial Studies, 30, 1539-1582.

Gorton, G. Kahl, M., \& Rosen, R. (2005). Eat or be eaten. a theory of merger waves. NBER Working paper No.11364.

Gogan, P. A. (2004). Mergers, acquisitions, and Corporate Restructurings. John Wiley\&Sons, Inc, New York.

Graham, J., Lemmon, M., \& Wolf, J. (2001). Does corporate diversification destroy value?

Working paper, Duke University.

Harford, J., Humphery-Jenner, M. L., \& Powell, R. G. (2012). The sources of value destruction in acqusition by entreched managers. Journal Financial Economics, 106, 247-261.

Harrison, J. S., Hart, M., \& Oler D. (2014) Leverage and acquisition performance. Review of Quantitative Finance and Accounting 43(3), 571-603.

Humphery-Jenner, M., \& Powell, R. (2014). Firm size, sovereign governance, and value creation. Evidence from the acquirer size effect. Journal of Corporate Finance, 26, 57-77.

Jakšić, D. Mijić, K. Zekić, S., \& Poljašević, J. (2015). Comparative profitability analysis of milk production companies to milk processing companies. Custos e @gronegócio, 11(3), 206-226.

Jensen, M. C. (1986). Agency costs of free cash flow, corporate finance, and takeovers. American Economic Review, 76, 323-329.

Mahmoodi M., \& Mahmoodi E. (2016). Foreign direct investment, exports and economic growth. evidence from two panels of developing countries. Economic research - Ekonomska istraživanja, 29(1), 938-949. 
Andrašić J., et al: The Characteristics of Takeover Targets: Evidence from Food...

Meeks, G. (1977). Dissapointing Marriage. A study of the Gains from Merger. Cambridge. Cambridge University Press.

Mesulis, R. W., Wang, C., \& Xie, F. (2007). Corporate governance and acquirer returns. Journal Financial Economics, 62, 1851-1889.

Moeller, S. B., Schlingemann, F. P., \& Stulz R. M. (2004). Firm size and the gains from acquisitions. Journal of Financial Economics, 73, 201-228.

Mudambi, R., \& Mudambi, S. M. (2002). Diversification and market entry choices in the context of foreign direct investment. International Business Review, 11, 3555.

Nikolić, I., \& Zubović, J. (2013). Structural Changes in Serbian Industry during Transition. Industrija, 41(2), 67-79.

North, D. S. (2001). The role of managerial incentives in corporate acquisitions: the 1990s evidence, Journal of Corporate Finance, 7, 125-49.

Offenberg, D. (2009). Firm size and the effectiveness of the market for corporate control. Journal of Corporate Finance, 15, 66-79.

Officer, M. (2003). Termination fees in mergers and acquisitions. Journal of Financial Economics 69, 431-467.

Palepu, K. G. (1986). Predicting takeover targets. A methodological and empirical analysis. Journal of Accounting and Economics, 8, 3-35.

Peng, M. W. (2006). Making M\&A fly in China. Harvard Business Review, 84(3), 2627.

Savoiu, G., Dinu, V., \& Ciuca S. (2013). Foreign Direct Investment based on country risk and other macroeconomic Factors. Econometric Models for Romanian Economy. Romanian Journal of Economic Forecasting,1, 39-61.

Schwert, W. (2000). Hostility in takeovers: In the eyes of the beholder. The Journal of Finance 55, 2599-2640.

Singh, R. (1997). Mergers, acquisitions and corporate restructurings. John Wiley\&Sons.

Song, M., \& Walkling, R. (1993). The impact of managerial ownership on acquisition attempts

and the market for corporate control. Journal of Financial and Quantitative Analysis,

28 ,

439-

The 457. http://www.apr.gov.rs/Portals/0/GFI\%202018/Obrazac\%20BON\%20zahtev\%2 02\%2025012018.pd

Wruck, K. H. (1990). Financial distress, reorganization, and organizational efficiency. Journal

Financial Economics, 27(2), 419-444. 